\title{
INDICES OF OBESITY DERIVED FROM HEIGHT AND WEIGHT IN TWO POLYNESIAN POPULATIONS
}

\author{
BY
}

\author{
J. GRIMLEY EVANS, M.B., B.Chir.(Cantab.), M.R.C.P. \\ Research Fellow in Clinical Epidemiology
}

AND

\author{
I. A. M. PRIOR, M.D.(N.Z.), F.R.A.C.P., M.R.C.P. \\ Director, the Medical Unit, Wellington Hospital, Wellington, New Zealand
}

\begin{abstract}
Khosla and Lowe (1967) have drawn attention to the usefulness of a reliable index of obesity derived from height and weight. From their analysis of data on 5,000 British men aged 15 to 64 years, they decided that the best index was weight divided by the square of height, thus confirming the conclusions of Bøe, Humerfelt, and Wedervang (1957) and of Billewicz, Kemsley and Thomson (1962). Their criteria for this choice was that the index should be highly correlated with weight but independent of height since, in the general population, obesity is unassociated with height. The other two indices examined, weight divided by height, and weight divided by the cube of height, were both significantly correlated with height, the first positively and the second negatively. A third criterion for an index of obesity to be used in epidemiological studies is its appropriateness for different populations and races. In this paper we examine the applicability of the various indices to two South Pacific Polynesian populations.
\end{abstract}

\section{Populations and Methods}

The two groups studied consisted of the entire population of the isolated coral atoll of Pukapuka in the Northern Cook Islands, and a sample of adults (20 years of age and over) living under town conditions on Rarotonga in the Southern Cook Group. Although of the same broad ethnic origin, the two populations live under very different environmental conditions. The Pukapukans live at subsistence level on a diet composed mainly of coconut, taro, and fish. The Rarotongans enjoy a cash economy with access to European types of food and canned goods. More detailed descriptions of the two groups have been published (Prior, Harvey, Neave, and Davidson, 1966). Heights, without shoes, were measured to the nearest half- inch using a steel tape on a wall; weights were measured to the nearest pound with subjects in a minimum of clothing, for which an allowance of $2 \mathrm{lb}$. was made. Skinfold measurements to the nearest millimetre were taken with Harpenden calipers just below the point of the right scapula and over the triceps at the mid-point of the right upper arm. Biacromial diameters were measured to the nearest centimetre using body calipers. The measure ments were made by one observer in Rarotonga and by the same observer and one other in Pukapuka.

\section{RESULTS}

Mean heights and weights of the populations are presented by age and sex in Table I (opposite); it will be seen that the Rarotongans are both taller and heavier on average than the Pukapukans. (Pregnant women have been excluded from the analysis.)

In Table II (opposite) we present zero-order linear correlation coefficients between height, weight, and three indices derived from height $(H)$ and weight $(W)$.

We have followed Khosla and Lowe (1967) in defining these as follows:

$$
\begin{aligned}
& I_{1}=\frac{W}{H} \\
& I_{2}=\frac{W}{H^{2}} \times 100 \\
& I_{3}=\frac{W}{H^{3}} \times 10,000
\end{aligned}
$$

The three indices were all inter-correlated with coefficients ranging from 0.54 to 0.99 , all highly significant $(P<\cdot 001)$.

Owing to the small numbers involved, the coefficients fluctuate between age groups, and in Table 
TABLE I

MEAN HEIGHTS AND WEIGHTS WITH STANDARD DEVIATIONS (IN BRACKETS), BY AGE AND SEX, IN RAROTONGA AND PUKAPUKA

\begin{tabular}{|c|c|c|c|c|c|c|c|}
\hline \multirow{2}{*}{ Sex } & \multirow{2}{*}{ Age (yrs) } & \multicolumn{3}{|c|}{ Rarotonga } & \multicolumn{3}{|c|}{ Pukapuka } \\
\hline & & No. of Subjects & Hoight (in.) & Weight (lb.) & No. of Subjects & Height (in.) & Woight (lb.) \\
\hline Male & $\begin{array}{l}20-29 \\
30-39 \\
40-49 \\
50-59 \\
60-69 \\
70-\end{array}$ & $\begin{array}{l}83 \\
44 \\
39 \\
39 \\
17 \\
16\end{array}$ & $\begin{array}{l}67.6(2.5) \\
67.9(2.2) \\
68.1(2.3) \\
66.9(2.2) \\
67.1(2.3) \\
66.4(2 \cdot 7)\end{array}$ & $\begin{array}{l}161 \cdot 8(29.0) \\
166.9(25.0) \\
178.2(32.5) \\
163.0(26.9) \\
172.1(32.9) \\
152 \cdot 9(26.4)\end{array}$ & $\begin{array}{l}43 \\
46 \\
33 \\
31 \\
19 \\
12\end{array}$ & $\begin{array}{l}66 \cdot 9(2 \cdot 5) \\
66 \cdot 3(2 \cdot 1) \\
65 \cdot 2(2 \cdot 2) \\
65.5(1 \cdot .8) \\
64 \cdot 8(1 \cdot 0) \\
64 \cdot 3(1 \cdot 9)\end{array}$ & $\begin{array}{l}151.9(16 \cdot 3) \\
154.9(21.8) \\
151.8(19.8) \\
160 \cdot 1(26.7) \\
158 \cdot 3(17.9) \\
139.8(20 \cdot 6)\end{array}$ \\
\hline Female & $\begin{array}{l}20-29 \\
30-39 \\
40-49 \\
50-59 \\
60-69 \\
70-\end{array}$ & $\begin{array}{l}73 \\
30 \\
39 \\
32 \\
20 \\
12\end{array}$ & $\begin{array}{l}63 \cdot 7(1 \cdot 7) \\
63.3(2 \cdot 5) \\
63 \cdot 5(2 \cdot 1) \\
62.5(2 \cdot 0) \\
63.0(2 \cdot 1) \\
60 \cdot 5(2 \cdot 3)\end{array}$ & $\begin{array}{l}150 \cdot 6(24 \cdot 3) \\
171 \cdot 2(34 \cdot 6) \\
189 \cdot 3(44 \cdot 0) \\
187 \cdot 3(50.0) \\
182 \cdot 5(58.1) \\
137 \cdot 0(39 \cdot 6)\end{array}$ & $\begin{array}{l}46 \\
42 \\
25 \\
30 \\
20 \\
9\end{array}$ & $\begin{array}{l}62 \cdot 2(2 \cdot 1) \\
62 \cdot 2(2 \cdot 0) \\
62 \cdot 0(1 \cdot 6) \\
61 \cdot 6(1 \cdot 5) \\
60 \cdot 6(2.4) \\
59 \cdot 6(2 \cdot 3)\end{array}$ & $\begin{array}{l}136 \cdot 0(15 \cdot 8) \\
149 \cdot 7(24 \cdot 5) \\
148 \cdot 7(26 \cdot 3) \\
149 \cdot 6(30 \cdot 3) \\
133.6(24 \cdot 7) \\
101 \cdot 8(20 \cdot 4)\end{array}$ \\
\hline
\end{tabular}

TABLE II

ZERO-ORDER CORRELATION COEFFICIENTS (ALL AGES POOLED BY Z-TRANSFORMATION) BETWEEN HEIGHT, WEIGHT, AND INDICES OF OBESITY

\begin{tabular}{|c|c|c|c|c|c|c|c|c|}
\hline \multirow{3}{*}{$\frac{\frac{\text { Sex }}{\text { Population }}}{\text { Index }}$} & \multicolumn{4}{|c|}{ Male } & \multicolumn{4}{|c|}{ Female } \\
\hline & \multicolumn{2}{|c|}{ Rarotonga } & \multicolumn{2}{|c|}{ Pukapuka } & \multicolumn{2}{|c|}{ Rarotonga } & \multicolumn{2}{|c|}{ Pukapuka } \\
\hline & Height & Weight & Height & Weight & Height & Weight & Height & Weight \\
\hline $\begin{array}{c}\text { Weight } \\
\mathbf{I}_{1} \\
\mathbf{I}_{2} \\
\mathbf{I}_{2}\end{array}$ & $\begin{array}{r}.44 \\
.25 \\
-.02 \\
-.21\end{array}$ & $\begin{array}{r}.98 \\
.92 \\
.90 \\
\end{array}$ & $\begin{array}{r}.55 \\
.33 \\
.05 \\
-.18\end{array}$ & $\begin{array}{r}.97 \\
.89 \\
.69\end{array}$ & $\begin{array}{r}.24 \\
.10 \\
-.02 \\
-.08\end{array}$ & $\begin{array}{r}.99 \\
.95 \\
.83\end{array}$ & $\begin{array}{r}.46 \\
.29 \\
.12 \\
-.01\end{array}$ & $\begin{array}{l}.98 \\
.92 \\
.82\end{array}$ \\
\hline
\end{tabular}

Bold coefficients are significant $(P<\cdot 05)$

II only the all ages coefficients, pooled by means of a Z-transformation, are shown.

Among males, these pooled coefficients show a pattern similar to that observed by Khosla and Lowe (1967) in their British population, that is to say, $I_{1}$ is positively, and $I_{3}$ negatively, correlated with height, while $I_{2}$ is unrelated to height.

Among females, $I_{1}$ is positively correlated with height in Pukapukans, but both $I_{2}$ and $I_{3}$ are independent of height in both populations.

Table III shows zero-order correlation coefficients between the various indices, height and weight and the sum of two skinfolds. Skinfold measurements have been validated as an indicator of obesity by body density estimations (Pascale, Grossman, Sloane, and Frankel, 1956; Seltzer, Goldman, and Mayer, 1965). Except among Rarotongan women aged 60 and above, Table III confirms that there is no relation within the population between height and obesity as estimated by subcutaneous fact. All the indices and body weight are correlated with skinfold measurements. The coefficients tend to be lower in Pukapuka owing to a greater error variance in the skinfold measure-

TABLE III

ZERO-ORDER CORRELATION COEFFICIENTS WITH "SUM OF SKINFOLDS", BY AGE AND SEX

\begin{tabular}{|c|c|c|c|c|c|c|c|c|c|c|c|}
\hline \multirow{2}{*}{ Sex } & \multirow{2}{*}{ Aco (yrs) } & \multicolumn{4}{|c|}{ Rarotonga } & & \multicolumn{5}{|c|}{ Pukapuka } \\
\hline & & Height & Weight & $I_{1}$ & $I_{2}$ & $\mathbf{I}_{\mathbf{3}}$ & Height & Weight & $I_{1}$ & $\mathbf{I}_{2}$ & I. \\
\hline Male & $\begin{array}{l}20-29 \\
30-39 \\
40-49 \\
50-59 \\
>60\end{array}$ & $\begin{array}{l}\cdot 14 \\
.06 \\
.03 \\
.18 \\
.14\end{array}$ & $\begin{array}{l}.86 \\
.71 \\
.88 \\
.75 \\
.86\end{array}$ & $\begin{array}{r}.89 \\
.76 \\
.91 \\
.80 \\
.84 \\
\end{array}$ & $\begin{array}{l}.87 \\
.78 \\
.90 \\
.83 \\
.87 \\
\end{array}$ & $\begin{array}{l}.80 \\
.74 \\
.86 \\
.82 \\
.81\end{array}$ & $\begin{array}{r}.04 \\
.04 \\
.15 \\
-.03 \\
-.13\end{array}$ & $\begin{array}{r}.29 \\
.59 \\
.55 \\
.85 \\
.67\end{array}$ & $\begin{array}{l}.35 \\
.65 \\
.61 \\
.89 \\
.70\end{array}$ & $\begin{array}{l}.37 \\
.67 \\
.64 \\
.90 \\
.70\end{array}$ & $\begin{array}{l}.30 \\
.64 \\
.60 \\
.88 \\
.70\end{array}$ \\
\hline Female & $\begin{array}{l}20-29 \\
30-39 \\
40-49 \\
50-59 \\
>60\end{array}$ & $\begin{array}{r}-.23 \\
-.05 \\
.17 \\
.03 \\
.44\end{array}$ & $\begin{array}{l}.74 \\
.83 \\
.90 \\
.83 \\
.90\end{array}$ & $\begin{array}{l}.79 \\
.86 \\
.90 \\
.85 \\
.91\end{array}$ & $\begin{array}{l}.80 \\
.86 \\
.88 \\
.86 \\
.90\end{array}$ & $\begin{array}{l}\cdot 81 \\
.83 \\
.84 \\
.85 \\
.88\end{array}$ & $\begin{array}{l}\cdot 11 \\
\cdot 17 \\
\cdot 19 \\
\cdot 06 \\
\cdot 14\end{array}$ & $\begin{array}{r}\cdot 61 \\
.78 \\
.78 \\
.71 \\
.73\end{array}$ & $\begin{array}{l}\cdot 73 \\
80 \\
\cdot 77 \\
\cdot 75 \\
\cdot 75\end{array}$ & $\begin{array}{r}\cdot 51 \\
\cdot 79 \\
\cdot 74 \\
\cdot 78 \\
\cdot 72\end{array}$ & $\begin{array}{r}.51 \\
.75 \\
.69 \\
.80 \\
.66\end{array}$ \\
\hline
\end{tabular}

Bold coefficients are significant $(P<\cdot 05)$. 
ments when two observers are involved instead of one.

Table IV presents means and standard deviations of $\mathrm{I}_{2}$ by sex and age group in the two populations.

TABLE IV

MEANS AND STANDARD DEVIATION OF I, BY AGE AND SEX

\begin{tabular}{|c|c|c|c|c|c|}
\hline \multirow{2}{*}{ Sex } & \multirow{2}{*}{ Age (yrs) } & \multicolumn{2}{|c|}{ Rarotonga } & \multicolumn{2}{|c|}{ Pukapuka } \\
\hline & & Mean & S.D. & Mean & S.D. \\
\hline Male & $\begin{array}{l}20-29 \\
30-39 \\
40-49 \\
50-59 \\
60-69 \\
>70\end{array}$ & $\begin{array}{l}3 \cdot 53 \\
3 \cdot 61 \\
3 \cdot 84 \\
3 \cdot 63 \\
3 \cdot 82 \\
3 \cdot 48\end{array}$ & $\begin{array}{l}0.57 \\
0.47 \\
0.68 \\
0.48 \\
0.63 \\
0.64\end{array}$ & $\begin{array}{l}3 \cdot 39 \\
3 \cdot 52 \\
3 \cdot 56 \\
3 \cdot 73 \\
3 \cdot 77 \\
3 \cdot 37\end{array}$ & $\begin{array}{l}0.25 \\
0.42 \\
0.33 \\
0.63 \\
0.44 \\
0.41\end{array}$ \\
\hline Female & $\begin{array}{r}20-29 \\
30-39 \\
40-49 \\
50-59 \\
60-69 \\
>70\end{array}$ & $\begin{array}{l}3 \cdot 72 \\
4 \cdot 27 \\
4 \cdot 69 \\
4 \cdot 79 \\
4 \cdot 56 \\
3 \cdot 71\end{array}$ & $\begin{array}{l}0.60 \\
0.85 \\
1.07 \\
1.21 \\
1.29 \\
0.89\end{array}$ & $\begin{array}{l}3.51 \\
3.86 \\
3.87 \\
3.93 \\
3.63 \\
2.87\end{array}$ & $\begin{array}{l}0.32 \\
0.57 \\
0.67 \\
0.71 \\
0.59 \\
0.58\end{array}$ \\
\hline
\end{tabular}

In addition to adiposity, two other factors contribute to overweightness: (a) muscularity, and (b) body width and depth, loosely termed frame size. We attempted to assess the contribution of the latter by means of measurements of biacromial diameter (BAD). Technically satisfactory measurements were available for 120 Pukapukan males aged 20 to 49 years. The measurements correlate with height $(r=0.59 ; \mathrm{P}<.001)$ and with weight $(r=0.62 ; \mathrm{P}<\cdot 001)$, but not with skinfold measurements $(r=-0.00)$. The linear regression equation relating $I_{2}$ to skinfold measurements and BAD was:

$$
\mathbf{I}_{2}=\underset{(\mathrm{mm} .)}{0.031} \underset{(\text { skinfolds })}{0}+\underset{(\mathrm{cm} .)}{0.042}(\underset{\text { BAD })}{0}-2.193
$$

In terms of standard regression coefficients $(0.583$ for skinfold measurements and 0.227 for BAD), skinfolds were $2 \cdot 6$ times as important as BAD in determining $I_{2}$ in this group. This does not tell us how comparisons between groups would be affected by differences in frame size (as defined) for a given height as might occur if the groups were of different racial origin. To estimate the effect of this, another linear multiple regression equation was derived summarizing the relation of body weight to height, BAD, and skinfold measurements:

$$
\begin{gathered}
\begin{array}{c}
\text { Weight } \\
\text { (lb.) }
\end{array} \\
+2.335 \text { (height) }+1.339 \text { (skinfolds) } \\
+2.762 \text { (BAD) } \\
\text { (cm.) }
\end{gathered}
$$

According to this equation an increase in BAD of $1 \mathrm{~cm}$. at any given height and skinfold thicknesses would be associated with an increase in body weight of $2.76 \mathrm{lb}$. ( 95 per cent. confidence limits of this estimate are 1.50 to 4.03 ). At the mean height of this group of men (66.19 in.), this would increase $I_{2}$ by $0.06(0.02$ to 0.09$)$, which may be compared with the standard error of the mean $I_{2}$ for this group of men of 0.04 .

\section{Discussion}

All the indices tested are essentially measures of weight corrected for height. The need to do this is indicated by the positive association between height and weight shown by the correlation coefficients of Tables II and III. The ideal index will make the correction without being affected by different regressions of weight on height, or by different distributions of these variables in populations. Our findings indicate that $I_{2}$ makes the most satisfactory correction of weight for height for the two sexes and two populations although, in women, $I_{3}$ would do as well. All the indices are strictly indicators of "overweightness", but their high correlations with the subcutaneous fat measurements suggest that, in these populations although not necessarily in all, they can for most practical pure poses be regarded as indices of obesity. This con clusion is further supported by the multiple regrese sion analysis indicating that $I_{2}$ is determined more by skinfold thickness than by biacromial diameter among the Pukapukan men studied.

On the other hand, multiple regression analysis suggests that differences in mean $\mathrm{I}_{2}$ between groups would be strongly affected by differences in frame size. Thus, in Pukapukan males aged 20 to 49 years, an increase of $1 \mathrm{~cm}$. in mean biacromial diameter at a fixed height and skinfold thickness would have increased the mean $I_{2}$ of this group by 0.06 , oneand-a-half times the standard error. How the findings in this small and isolated group of subjects would compare with other genetically less homogeneous populations is questionable. However, the coefficients in the multiple regression equation given above do not differ significantly from those found in a similar analysis of a community sample of 119 New Zealand European males aged 20 to 49 years (Prior and Morrison, 1965). The implication is that comparisons between groups using $I_{2}$ as an index of obesity should be made with caution unless there is evidence that the means and distributions of body frame size are similar. (Our use of biacromial diameter has been exploratory and does not imply that it is established as an adequate measure of frame size.) Similar considerations will presumably apply to muscularity, which may affect 
the comparison of groups of different age composition.

Our findings in the two Polynesian populations confirm the work of Bre and others (1957) and of Billewicz and others (1962) and Khosla and Lowe (1967) in indicating that weight/height ${ }^{2}$ is a satisfactory method of correcting weight for height within genetically homogeneous groups and probably reflects variations in adiposity to a greater extent than variations in frame size. We consider, however, that the index should be interpreted with caution as a basis of comparing the mean obesity of different racial groups.

\section{SUMmary}

In two South Pacific Polynesian populations the index $\mathrm{W} / \mathrm{H}^{2} \times 100$, where $\mathrm{W}$ is body weight and $\mathbf{H}$ height, has been shown to be a satisfactory index of over- or under-weightness, in that it is independent of body height. Alternative indices $\mathrm{W} / \mathrm{H}$ and $\mathrm{W} / \mathrm{H}^{3}$ are unsatisfactory, in that they correlate with height in one or both sexes. $\mathrm{W} / \mathrm{H}^{\mathbf{2}}$ correlates highly with adiposity, as measured by skinfold thickness. Multiple regression analysis of one group of men aged 20 to 49 years suggests that $\mathrm{W} / \mathrm{H}^{2}$ was determined more by adiposity than by frame size, as indicated by biacromial diameter (BAD). The same method of analysis, however, suggested that fairly small differences in mean BAD at a given height would have important effects . on the mean index of different groups. It is considered that $\mathrm{W} / \mathrm{H}^{2}$ makes a satisfactory index of overweightness (mostly obesity) within genetically homogeneous groups, but may be misleading if used as an index of obesity for between-group comparisons.

This work was supported by grants from the Medical Research Council of New Zealand and the World Health Organization. J.G.E. receives a grant from the Medical Research Distribution Committee of the Golden Kiwi Fund of New Zealand. Thanks are due to the Department of Scientific and Industrial Research for help with data processing.

\section{REFERENCES}

Billewicz, W. Z., Kemsley, W. F. F., and Thomson, A. M. (1962). Brit. J. prev. soc. Med., 16, 183 (Indices of adiposity).

Bøe, J., Humerfelt, S., and Wedervang, F. (1957). Acta med. scand., Suppl. 321 (The blood pressure in a population).

Khosla, T., and Lowe, C. R. (1967). Brit. J. prev. soc. Med., 21, 122 (Indices of obesity derived from body weight and height).

Pascale, L. R., Grossman, M. I., Sloane, M. S., and Frankel, T. (1956). "Correlation between Thickness of Skinfolds and Body Density in 88 Soldiers" in "Body Measurements and Human Nutrition", ed. J. Brozek, p. 55. Wayne University Press.

Prior, I. A. M., Harvey, H. P. B., Neave, M. N., and Davidson, F. (1966). "The Health of Two Groups of Cook Island Maoris". Special Report Ser., 26. Medical Statistics Branch of Department of Health, Wellington, New Zealand.

- and Morrison, R. B. I. (1965). "The Carterton Study". Unpublished observations.

Seltzer, C. C., Goldman, R. F., and Mayer, J. (1965). Pediatrics, 36, 212 (The triceps skinfold as a predictive measure of body density and body fat in obese adolescent girls). 